\section{血管再生医療における臨床試験デザイン につルて}

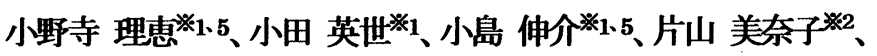
川本 篤彦*2、浅原 孝之*3、丸井 晃*4、西村 和修*4、 ornider@kuhp.kyoto-u.ac.jp 米田 正始*4、村田 桂子※5、津村 はやみ*1.5、手良向 峪*1.5、福島 雅典*1.5、古瀬清行*1

【背景】関西医科大学、自治医科大学、久留米医科大学各病院の申

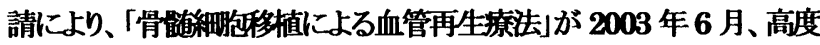
先准医療の適用対象になった(公的医療保険給付)。

【目的】高度先准医療適用承認の根批の一つとなった松原らの論文 「骨㿥維胞の自己移植による下肢虚血患者一の血管新生療法:パイ ットスタディーランダム化コンロール詰験1)を蜢床試験の評価手法で ある Thial Assessment Procedure Scale (TAPS) 2)を用いて言佃し、 問題点を明らかにする。また、今後の血管再生治㙩の躁休試験を行う 漈の留意点を提案する。

【方法】1991 年 Jerome Levine が蹦休試験の品質評価老目的に 作成した系統的な技法であるTAPSをもちいて論文の評価を行なう。

【結果】松原らの研究をTAPSで評佃した結果不十分と考えられる点 が幾つかあった。TAPS の項目に沿って述へると、「III. デザイノの 特徽 C) 被轸者の割付け」においてパイロットスタディの症例数設 定根扰が不明、「IV. 治療の特徽 A)記述において細胞の品質管理 に関する手順が不明、「B）投与量において投与量の設定根拠の 記载なく、投与部位・投与方法が不明、「VI. デー仅集 A) 評価の 籁网」において Primary outcome が Safety にも関からす、安全性 データの 収集籁用および力法が不明、「B）評価力法において多 のエンドポイトがあるが、それらの設定根找や相互の 関連が不明、 「VII. データ解析 B) データ表示」においてベースラインでの安静 時痛を有する患者の割合が不明であった。

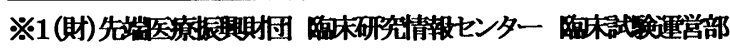

T650-0047 神户市中央区港島南町 1-5-4

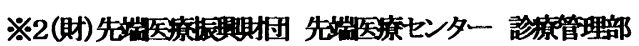

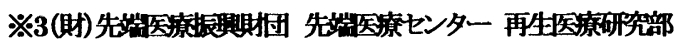

※4 京都大学大学院矢学研究科器官外科学請座 心清血管外科

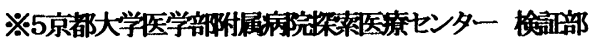

これより今後、血管再生医療の湢床圾输を行う祭の留意点は、(1)移 植細胞の品質保証 (2)治療方法の規格化 (3)予期される有害事象の 評研とその対応 (4)エンドポイトの設定であると考える。

「移植細胞の品質保証」における問題点は、自家細胞移植におい ては細胞自体患者個人で準徣しなけれはならないため大量生産が不 能であり、品質保証が難しい点にある。その対応策は「移植細胞の概 要書の作成」と考える。その内容は嵒床訊験開始前にクリアすべき項 目を記载するべきである。具体的には、(1)目的 (2)原材料となる細胞 について (3)細胞の培盖方法 (4)細胞以外の)原材料について (5)最 終的に治療で用いられる緗胞について (6)品質管理 (7)非襙床試験 の総括 8これまで行われてきた関連臨林試験についてと考える。

「治療力法の規格化」における問題点は、細胞移植方法に関するコ ンセンサスがないことである。そのための策として、個々の訊験にお いて治療者間差が発生しないように細胞移植方法(1部位あたりの投 与量、投与部位の設定)規格化を行なうこことである。

また、自己細胞移㮌は拒絶が起こりにくいといら点て安全であると考 えられているが、細胞採取は侵襲的であり危険が伴う。そのため予期 される有害事象の評価とその対応策を考えておくことは重要である。

さらに、エンドポイントの設定にも問題点があり、これまで慢性重症 下肢虚血患者に用いられてきた楽剂は 抗血小板郕、PG製風、血管 㹡張郕、抗凝固剤、血栓溶解剂、抗高脂血症郕 等で、そのどれも 血管新生するものではないためどのような評価指標がよいか不明で あるということである。そのために今後は、現存の評価指標を信賴性・ 妥当性の観点から評洒し、必要であれは新しいスケールを作成する ことが必要であると考える。

【考察】先行研究の評価から今後問題となることが予想されるのは、 (1)移植細胞の品質管理・投与量設定方法・投与方法 (2)サンプルサ イズの設定 (3)エンドポイルの選択 (4)安全性評価の方法において である。また、試験計画時の留意点は、(1)移植細胞に関する概要書 の作成 (2治療方法の規格化 (3)予期される有害事象の評価とその 対応 (4)エンドポイント設定根批の明示 であり、今後の対応が望ま れる。

【文献】 1) E Tateishi- Yuyama, H Matsubara, et al. Lancet, 360: 427-435. 2002. 2) J Levine. In: GUIDE TO CLINICAL TRIALS. Bert Spilker (Eds), pp. 772-792. Lippincott Williams \& Wilkins. 1991. 